\title{
Examination of existing arguments on business oriented towards poverty reduction with the case of people with disabilities in Vietnam
}

\author{
Nghia Chi Nguyen
}

Received: 3 January 2012 / Accepted: 31 July 2012 / Published online: 17 August 2012

(C) Springer Science+Business Media B.V. 2012

\begin{abstract}
With an eye ultimately to answering the question of how business can alleviate poverty completely, the paper examines existing arguments about the approach of business to poverty reduction with the case of people with disabilities living in poverty in Vietnam. The paper suggests that business should take the knowledge and potential of poor people into consideration in its interfaces with different types of poor people: consumers, workers, property owners, etc. Furthermore, investigating how business can help reduce poverty while still earning a profit and ensuring customer satisfaction limits research on business approach to poverty, since it assumes that business will have some "not-for-profit" purposes. The findings point out that businesses with "not-for-profit" purposes serve as a promising area for further exploration and research of business approach to poverty alleviation.
\end{abstract}

Keywords Potential and resources of poor people - Semantics of business · Not-for-profit purposes · Business oriented to poverty alleviation ·

Business by the poor $\cdot$ Awareness

\section{An emerging area in business studies}

Introduction

In recent years, the phrase "business for poverty" has been frequently mentioned and received a lot of attention in both the business and academic worlds. There have been an increasing number of articles, books, and frequent exciting forums and workshops on this topic. In these workshops, we can easily recognize the variety of participants: students, enterprises, consultants, university professors, and government representatives. It is rare for so much public attention to be directed to such a topic. The purposes of these participants are also varied: students interested in finding a new approach to activist work, enterprises struggling to find new markets in the current negative economic

\footnotetext{
N. C. Nguyen $(\bowtie)$

Regional Management Research Institute, Aomori Chuo Gakuin University, 12-1 Kanda,Yokouchi, Aomori, Aomori, Japan 030-0132

e-mail: nghia-nguyen@aomoricgu.ac.jp
} 
climate, non-governmental organizations hoping to improve efficiency in assisting developing nations, and business scholars passionate about pushing research forward.

However, these attentions from the international community have not been considered a positive signal for poverty reduction, because poverty cannot be thoroughly alleviated by just looking at one or a few aspects of the problem. The present paper aims to examine and discuss the business approach to poverty reduction with the purpose of finding effective ways to alleviate poverty, rather than to take advantage of the poor to benefit business.

\section{Arguments about the business approach to poverty reduction}

One critical argument about business approaches to poverty reduction stems from Prahalad and Hart (2002), who propose a market-based perspective considering the poor as customers. This leads to a critical discourse on emphasizing the poor as consumers. For example, Karnani (2007) stated that generating jobs and income for the poor should be the main thrust of both corporate and government in poverty alleviation.

The current paper uses the case of people with disabilities in Vietnam to examine the existing arguments thoroughly not in order to deny them but to make an analysis of their strength. Furthermore, it aims to point out unpopular truths not captured by prior work which might be small, but might also be important in helping poor people get out of poverty.

\section{Consumption side and income-generating side}

The consideration of the poor as part of the value chain has been the basis of many scholarly arguments. The market-based perspective emphasizes that business-based poverty reduction can be carried out through the development of new markets and innovative approaches. This perspective regards poor people as potential customers of multinational companies and points out how these companies can improve the efficiency of activities for the poor by selling them products and converting them into markets. This viewpoint has attracted the interest of companies and even of governments. Companies have seen it as an innovative approach when the saturation of domestic and other traditional markets as well as the demand of the international community for the implementation of corporate social responsibility is increasing. This new point of view has been argued to be able to lead companies to a situation of sustainable development that can help explore new sources of growth and at the same time deal with international opposition on current corporate social responsibility practices. ${ }^{1}$

\footnotetext{
${ }^{1}$ Prahalad (2005) argued that four million people living at the bottom of the world can serve as untapped markets with an economy of more than \$13 trillion PPP, which serves as new sources of growth for MNCs. On the other hand, companies are suffering from international opposition for taking proper responsibility of dealing with social issues. Though social responsibility of business used to refer to matters of relationship between private and public ethics, responsibility of businessmen towards employees and respect to the community culture, the focus has been shifted towards demanding business to take social responsibility for not only social consequences of its activities but also problems of the society itself (Drucker 1974). However, Porter and Kramer (2006) criticized that corporate social responsibility (CSR) activities fall into formalism with CSR reports, public relations, and media campaigns, and their disconnection from business and strategy prevents companies from exploring valuable opportunities to benefit society. Therefore, exploring opportunities and performing innovations at the bottom of the economic pyramid are supposed to help MNCs to benefit the poor with more access to goods and services, convert them into new markets, and at the same time take their social responsibilities.
} 
Although this approach is viewed as effective, companies seem to ignore the possibility that it will cause the companies to answer higher expectations of solving social problems. Treating poor people as customers accompanies the questions of "how to help them escape from the poverty", "whether the problems have been solved or not". Therefore, the key in this regard is not products, services, or customer value, but standards to assess the effectiveness of poverty alleviation. The neglect of this issue will lead to shortcomings in the business approach.

For example, according to the state News Agency of Nigeria, Nigerian schoolchildren who received cheap laptops from The One Laptop Per Child Project, which aims to promote learning with laptops to deal with the problem of lack of teachers, have used them to explore pornographic sites on the Internet, and explicit sexual materials have been found saved in the laptops (Reuters 2007). School laptop projects have been implemented by many companies, as they can lead to increased consumption of accessories and related products. However, the more attention these issues receive, the further assessment standards move away from traditional corporate criteria such as profit, affordability, or customer satisfaction of individual customers and towards problem-solving effectiveness; for example, how many students can better their grades. In other words, even though schoolchildren feel satisfied with the wrong ways they use laptops, for example, exploring pornographic sites, laptops are primarily supposed to innovatively deal with the problem of lack of teachers through promoting learning. Therefore, satisfaction of schoolchildren is not the standard for effectiveness of the solution, but whether the primary goal has been met or not is the one.

Karnani (2010) criticized this approach on the basis that the poor spend a high share of their household income on alcohol, criticizing companies for marketing alcohol to the poor. However, from a different angle, high alcohol consumption is not the fault of companies but is due to the lack of health knowledge of poor people. When they become aware of ways to solve their own personal and family difficulties, poor people will not spend their money on alcohol any longer. Another aspect of the question is where money for alleviating the condition of the poor will come from. Karnani (2007) emphasized the importance of generating income for the poor. Moreover, Karnani (2010) showed this income can come from fostering modern enterprises that provide employment opportunities for the poor, and that this is the responsibility of government. To thoroughly examine these issues, the author chooses to study the case of disabled people, who are regarded as poor people, in Vietnam.

Examination of existing arguments with the case of people with disabilities in Vietnam

People with disabilities in Vietnam The disabled are chosen for the present study because among six million people with disabilities in Vietnam (about $6.4 \%$ of the population), $80 \%$ have to depend on their immediate family or relatives in rural or urban areas; $32.5 \%$ are poor (double the overall poverty rate); and $24 \%$ do not have permanent homes. These difficulties have prevented people with disabilities (PWDs) from having access to health services, education, vocational training, jobs, and transport, which makes it harder to better their lives and integrate them in the community (Giang 2010). Not all families have sufficient means to take good care 
of people with disabilities. A survey on disability by the Vietnamese Ministry of Labor, Invalids, and Social Affairs (MOLISA) on disability in 1995 showed that the majority of households that have disabled people have low living standards: $32.5 \%$ live in poverty, $58 \%$ are "average," $9 \%$ "better off," and $0.5 \%$ "wealthy." Just $1 \%$ of families, virtually all with higher incomes, manage to create favorable conditions for disabled family members. Therefore, investigating the case of people with disabilities in Vietnam as one aspect of poverty will be useful.

Issue on the role of government Karnani (2010) stated that it is necessary for the government to take a central role in fostering enterprises that can provide employment for the poor. In Vietnam, the Communist Party and the government have promulgated several policies and measures to take care of people with disabilities and have called for support from all classes of people. MOLISA has also developed policies to promote job placements for PWDs by setting a quota for hiring disabled people. Enterprises have to pay for each unfilled position and payments come into the compensation employment fund for disabled people. Bad health and the diversity of disabilities prevent PWDs from being highly productive in the workplace, whereas there is still some prejudice about employing people with disabilities. Thus, many employers prefer to make payments towards the fund.

The results of a survey on the employment of disabled people in four provinces in Vietnam by the Institute for Social Development Studies (Duong et al. 2008) and a survey of 70 enterprises of different sizes (Minh 2007) showed that $30 \%$ of the surveyed enterprises confirmed that they might employ the disabled. In addition, these enterprises require the disabled to have certification to do jobs like accountants or computer technicians. Without training supports from companies, it will be hard for them to acquire certifications. However, "it is still not easy for the disabled to find a job even when they are well trained. In fact, $70 \%$ of graduates from our center are still jobless," according to Nguyen Cong Hung, director of The Will to live Center, Nghe An Province (Dat 2010).

If it is compulsory for companies to employ the disabled, they may be resistant. They may discriminate against disabled and other employees. For example, a company owned by a man named Son hired 72 workers, among whom were four disabled employees. Son's decision to hire disabled people came from his sympathy with their needs. He was also proud to be able to contribute to society. However, the PWDs at his company received much lower salaries compared to their co-workers. The average salary at the company is 1,000,000-1,100,000 dong (₫) per month for key workers; for assistant workers, it is 700,000-800,000₫; for disabled workers, it is 350,000 $400,000 ₫$. The reason provided by the employers is that because the working capacity of PWDs is very low. A product takes them from 2 weeks to a month to complete, whereas a key worker would finish in 2-3 days. In fact, Son does not want to hire more disabled workers, since his company must pay for the needed vocational training. Training for PWDs is also difficult due to their often lower educational level and takes a long time compared to training "normal" apprentices (employer, wood and carpentry company in Quang Nam; Duong et al. 2008).

PWDs are also stigmatized by co-workers, who often consider PWDs as troublesome or as impeding production efficiency. Government reports have documented how stigma and discrimination have hampered the advancement of PWDs. For 
example, in a survey of 720 PWDs in Hanoi, Da Nang, and Ho Chi Minh City conducted by the Committee for Social Affairs of the National Assembly, nearly $7 \%$ of PWDs reported that in their own families, they were treated worse than other family members; $13 \%$ said they were badly treated by the community (Duong et al. 2008). A USAID assessment also showed that, in education, children with disabilities (CWD) were occasionally rejected by schools and/or became the target of unkind attitudes from other non-disabled students who exposed CWD to taunts and isolation. In the workplace, the level of stigma and discrimination was even higher, with employers unwilling to take the "risk" of employing workers with disabilities (USAID 2005). In fact, tackling stigma and discrimination against PWD has now emerged as a core issue for the government. However, changing long-held perceptions and attitudes is by no means easy, and requires monumental effort from all sections of society (Duong et al. 2008). It is clear that the public's attitude towards the disabled cannot be controlled completely. Difficulties due to lack of education, lack of training, and public concern make it harder for people with disabilities to escape from unemployment and poverty. This also means that government regulation of employment for the disabled has solved only part of the problem.

Issue on the right to choose Karnani (2010) mentioned that if the poor could choose, they would like to be employed rather than self-employed. However, the decision still ultimately falls on employers only. Employers may have their own reasons to choose the poor as employees or not.

For example, the disabled might not be suitable for the production line or for other work conditions. Duong et al. (2008) showed that for the cohorts of PWDs aged 15 and above, the proportion currently working was low across all three provinces. One third of PWDs interviewed in Thai Binh had been employed but were no longer at the time of the survey. Disability was the main reason given why they could no longer work. For Quang Nam-Da Nang and Dong Nai, the proportions were 30 and $27 \%$, respectively. In all three provinces, a high percentage of respondents had never worked. In Dong Nai, almost one in every two PWDs aged 15 and above had never worked. In Quang Nam-Da Nang, it was one in every three. In Thai Binh, the proportion was almost $40 \%$. As explained in the next section, disability was the major cause of their unemployment.

The reason for this is that most disabled employees lack working knowledge and skills. In education, about $35.83 \%$ of PWDs are illiterate, $12.58 \%$ are literate, $20.74 \%$ have finished secondary school, and $24.13 \%$ have finished high school. Most $(97.64 \%)$ of the disabled have not received vocational training (Caritas Vietnam 2010). Therefore, the majority of disabled Vietnamese work in fields that do not require special training, such as agricultural labor or lottery-ticket sales. The majority of working PWDs were in the agricultural sector as farmers and the factory sector as unskilled workers. In Thai Binh and Quang Nam-Da Nang, less than $10 \%$ of respondents were in trade or services. In Dong Nai, however, the proportion was much higher - about one quarter of PWDs were working in these occupations. In general, the disabled have not satisfied the needs of enterprises, and companies have had difficulty in addressing the health and other needs of the disabled.

The above-mentioned statistics as well as discussion on the issue on the role of government showed that there are many reasons for the fact that enterprises refuse to 
employ PWDs, such as low working capacity, working knowledge, and skills of PWDs. The key matter does not lie in answering the question whether the poor should be self-employed or employed, but how to help the poor get to work to escape from poverty. International Labor Organization put the emphasis on work as the principal route out of poverty (International Labor Organization 2003), so it is not necessarily limited to only employment, but self-employment does also serve as a source of work for poor people.

Issue on entrepreneurship by poor people Karnani (2010) stated that only a small number of poor people can become entrepreneurs. The article argues that the poor do have the potential to become entrepreneurs. Entrepreneurial activities by the poor often come from efforts to solve their own problems, become self-independent, and above all create their own lives. In entrepreneurship research, Brenner (1983) stated that the determination to struggle against an economic set-back seems to be an entrepreneurial characteristic. On the other hand, International Labor Organization (2003) pointed out that "people in poverty go through each day with the will to survive, but without the support and possibilities to move up the ladder of opportunity." Therefore, the poor, living with the will to survive, to struggle against poverty issues, can become entrepreneurs. The small number of poor people as entrepreneurs cannot be taken as the reason to make little of the entrepreneurship approach by the poor in poverty reduction. This reasoning by Karnani is not persuasive. Since there is no universal panacea for all poverty issues, their existence cannot be neglected and their solutions can give effective and important hints for solving the problems.

A main part of the argument of this paper is that it is hard to come to consensus between business perspectives on alleviating poverty because each captures some aspect of the problem. The key is to be holistic, and not take aspects such as work or home life in isolation. The complete refusal or even adoption of any approach would in fact limit its usefulness.

\section{Consideration of businesses oriented towards poverty reduction}

Business solutions to poverty reduction are often discussed as if they could be readymade. Based on the deep analysis of these arguments and critics of their limits, the paper wants to put the emphasis on the necessity of a deeper and more multifaceted understanding of the issue.

The multidimensional view of poverty

Though there has been a considerable increase in studies on business approaches to poverty reduction, most business solutions tend to neglect the multidimensional nature of poverty. Instead, poverty has been reduced to a matter of income. However, the concept of "income" is as problematic as that of "poverty," since it is quite difficult to determine where the poverty line should be (Townsend 2006). Though certain amounts such as US\$1 or \$1.25 are often used as benchmarks, they do not tell the whole story. For example, Townsend (2006) argued that material and social 
deprivation should be also included in judging whether a person is in poverty or not. The World Bank (2000) stressed that "poverty is more than inadequate income or human development - it is also vulnerability and a lack of voice, power, and representation." The Nobel Prize-winning economist Amartya Sen also viewed poverty as a deprivation of basic capabilities rather than merely of income (Sen 1999).

Eliminating poverty requires a deep understanding of its true nature. However, not business but international organizations are most aware of this view. International Labor Organization (2003) and Vandenberg (2006) also emphasized the fact that these dimensions tend to reinforce each other and interlock to keep the poor in a state of poverty: "Poverty is a vicious circle of poor health, reduced working capacity, low productivity and shortened life expectancy" (International Labor Organization 2003). The complexity of poverty must be understood and not neglected, and these aspects all form parts of it. Depending on a business's goal, in the case of interfaces between business and poverty, business should figure out what to do to contribute to poverty reduction, since there is no single manual for poverty elimination.

The focus on the poor

The poor are mostly underestimated and even neglected in existing arguments on business solutions to poverty reduction. Instead, the roles of multinational companies, NPOs, and governments are often highlighted. The poor seem to be passive actors in solutions created by others. However, the poor can be self-employed people, employees, consumers, etc. Therefore, considering solutions without looking at the variety of life circumstances of poor people and imposing a general solution will not have good results. For example, job creation is not necessarily the key solution; neither is supplying products or services. We need a change of view. Recognizing the diversity of poverty issues and poor people helps scholars attain a broader view of poverty and avoid seeing the poor as merely "poor consumers" or "poor workers." However, this perception causes much difficulty for scholarly work, due to the complexity of poverty and variety of people's circumstances. The current paper argues that one common point shared by many poor people is selfdefined problems.

Theory of human problem solving (study of how human beings solve problems for application in clinical treatment) proposes that "people are hardly ever motivated to solve problems that have been defined for them by others. It is essential, therefore, that the problems to be dealt with should be ones as seen as expressed by the individuals who have them" (Priestly et al. 1978). To state it another way, it is only when someone comes to an awareness of their problems on their own that they are motivated to solve them. The paper argues that this should be seen as the core principle of any approach to poverty reduction, even a business approach. Arguments on the relative importance of supplying the poor with products, services, or job opportunities and of the role of enterprises and governments are not inappropriate. However, poor people's awareness of their own difficulties is the factor needing deep consideration. It is the main source of poor people's motivation to work, live, and struggle for survival. 
Solutions based on the self-awareness and potential of the poor

The complexity and vicious cycle of poverty are hard to come to grips with since they vary widely depending on place, time, and other situational factors. However, the solutions can be sketched based on the self-awareness and potential of the poor.

As mentioned above, "poverty is a vicious circle of poor health, reduced working capacity, low productivity and shortened life expectancy," and "people in poverty go through each day with the will to survive, but without the support and possibilities to move up the ladder of opportunity," (International Labor Organization 2003). This means that poor people are the victims of a vicious circle that keeps them deep in poverty despite their will to escape from it. Most of them have an awareness of their problems in their struggle against poverty, and desire social recognition, not compassion.

"Most people pity disabled persons, but we should not be pitied. We do study hard, thrive, depend on each other and work like 'normal' people"

"We, persons with disabilities, never lose to any obstacle or difficulty, we always try by all means to survive"

"We have disabilities but we are not useless, we have the desire to work so that we can earn incomes, pay living expenses by ourselves, support our family since it can help release the misfortune in our bodies"

"If we cannot manage to do anything, we will be despised by the society and our families also become unhappy"

(said poor people with disabilities)

The fact given by Karnani (2010) that poor people spend a high share of household income on alcohol can be observed from a different angle, for instance, that those poor consumers lost the will to survive and the awareness of struggling against poverty. From a more positive perspective, International Labor Organization (2003) also highlighted the creativity of the poor in living their lives and dealing with their problems: "Simply coping with poverty demonstrates the resilience and creativity of the human spirit. In many ways, the working poor are the ultimate entrepreneurs."

2006 Nobel Peace Prize winner Muhammad Yunus always upholds the idea of creativity of the poor and puts emphasis on self-employment as the key solution to poverty reduction, saying "the poor are very creative. They know how to earn a living and how to change their lives" (2007). Yunus's words ring true: "Poor people are just as human as anyone else. They have just as much potential as anyone."

Therefore, "All they need is opportunity," and the birth of Yunus's Grameen Bank and its success in giving microloans to millions of borrowers works as an innovative solution bringing about opportunities for self-employment to the poor. Grameen has reported that $68 \%$ of borrowers and their families have crossed the poverty line and the remaining families are moving steadily towards the poverty line 
from below (www.grameen.com). "If we want to help poor people out, one way to do that is to help them explore and use their own capability," says Yunus.

Certainly, microfinance is not the only answer, but the crux of any solution lies in how to activate the potential of poor people. In some cases, it is also the awareness of struggling against poverty that helps the poor themselves constantly investigate their own problems, activate their potential to deal with problems, and even stimulate the creative power to generate solutions to their poverty issues. The challenge for business approaches to poverty reduction is not to apply solutions inflexibly to problems of "poor consumers" or "poor workers," but how to generate creative solutions based on stimulating the selfawareness, potential, and capacity of the poor.

Hoang Minh Co., Ltd Hoang Minh Co., Ltd, located in Binh Dinh Province, Vietnam, is a business established and operated by disabled people to produce three-wheeled motorcycles for people with disabilities, with the shared philosophy of "abandoning the thought of awaiting sudden presents of life and creating our lives by ourselves" The founder, Vo Dinh Minh, a disabled person from his childhood, used to suffer much inconvenience in daily activities and had difficulty finding a suitable job. He studied to be able to improve the normal two-wheeled motorbike into a creative three-wheeled motorbike with a reverse gear that could deal with obstacles and address mobility needs. Vo started a business to employ other disabled persons, provide them education and vocational training. They manufacture three-wheeled motorbikes with reverse gears for people with disabilities.

Unlike normal enterprises, Hoang Minh was created and is managed by and for people with disabilities. Therefore, working hours are also set to suit their physical needs, running from 07:00-11:30 and 13:30-17:00 (7 h a day). Newcomers can have food and accommodation in the first month as the first step toward svocational training and education, and learn the techniques for motorbike construction developed by Vo. From the second month, they enter the production process with a salary of $300,000 ₫$; by the third month, salary is 600,000-700,000₫. Average monthly income is for all employees is 1 million dong, almost double the per capita income of 520,000₫ in Binh Dinh Province.

Most Vietnamese people with disabilities cannot depend on mass-produced electric three-wheeled bikes, because they are too poor to afford them. Therefore, Hoang Minh employees convert available two-wheeled motorbikes into three-wheeled bikes with a price of about 2.5-2.7 million dong using a maketo-order production method. The strength of this business is that it is run by people with disabilities and its products are produced by people with disabilities for disabled customers. The employees have a strong idea of their customers' needs.

With these bikes, people with mobility disabilities can move around without difficulty or inconvenience. However, they still cannot climb stairs, and for these poor people there is certainly no escalator or elevator at home. This is another issue that is implicitly understood by Hoang Minh employees, who experimented successfully with an electric wheelchair that can enable mobility-disabled people to use stairs. In the near future, these electric chairs will be perfected and launched on the market. 
In the short time since it began, Hoang Minh has manufactured many of these devices to help people with mobility disabilities get around. The disabled employees of Hoang Minh serve as a bright mirror reflecting the energy, determination, and desire of people with disabilities who never lose to fate, overcome physical pain, and create pleasant lives.

Duc Hien Co., Ltd Duc Hien Co., Ltd. was established in 2007 by Duc Hien with the primary goal of creating job opportunities for PWDs and accommodating their needs with the philosophy of "We are people with disabilities, but we have no product with disability". The company has 45 employees, 36 of whom $(75 \%)$ are disabled. The company was named after its founder to stress that it is a business enterprise, not a charity organization. The name also shows the employees' willingness to compete and take responsibility for their work rather than begging for help or living on the sympathy of others. Employees, who used to face difficulties in finding jobs, are taken in and work in "SVK Teams" (therefore, the smallest production unit is an SVK team, not a person). Each team must exhibit three qualities:

- $\mathrm{S}$ is "suc khoe" (health, enabling employees to work and perform different production processes)

- V is "van hoa" (knowledge, learning about the job and skills)

- $\mathrm{K}$ is " $k y$ thuat" (technique, performing tasks well)

Each team can have three, four, or five members, as long as it achieves the SVK elements. The members are likened to the fingers on a hand, which are not equal but can form an intact hand with more power than the sum of its parts. New members are automatically assigned to teams needing members. Each SVK team has a team leader, who is voted in by the other members upon the agreement of the company director. Team leaders change every 3 months. Each team decides their production quantity and hours; they can work for 3-, 7-, or 10 -h shifts depending on their health. The average monthly income is about $600,000 ₫$.

These two companies are examples of creative products and creative methods of production created by the poor themselves to help them overcome their weaknesses and inspire them to struggle against life constraints and enjoy better lives.

Business oriented for poverty alleviation

The semantics of "business"

Business-related terms such as business model or business plan are usually the terms seen as in need of definition, rather than the simple term business. Business appears to be an ill-defined and ill-explored term assumed to be too obvious to need discussion. Existing definitions share the point that business is "a legally recognized organization designed to provide goods, services, or both to consumers or tertiary business in exchange for money" (Business Encyclopedia). Some add that the purpose of that activity is profit: "commercial enterprise, profession, or trade operated 
for the purpose of earning a profit by providing a product or service" (Dictionary of Business Terms). However, "business" can also refer to "a person's regular occupation, profession, or trade" (New Oxford American Dictionary). Though the term refers to provision of goods or services to consumers, it is not necessarily for the purpose of profit maximization, since sometimes it refers to what a person usually does as their profession or occupation.

On the other hand, in business studies, the term is described as being composed of four major components: customer interface, core strategy, strategic resources, and value network (Hamel 2002). These components are often investigated under the prejudicial effect of the "profit assumption," but they are also often used to make a neutral analysis of how firms gain competitive advantage in the marketplace.

\section{"Business" in poverty reduction}

This paper aims to investigate business in a broad sense, not merely referring to profit but to a person's regular occupation, profession, or trade. In order to discuss how business can help alleviate poverty, the paper looks at:

- Business motives: Why the business wants to target poor people.

- The specific mission of the organization: How the organization intends to make a difference in society and what results will be seen as meaningful.

- How business can make good use of its interfaces with poor people.

On the other hand, as mentioned above, poverty is multidimensional and varies according to sociocultural context. Vandenberg (2006) mentioned about five groups of poor people: consumers of goods/users of services; employees; the unemployed, who may obtain employment from enterprises; owners of micro- and small enterprises; and dependents of the preceding individuals. The paper uses these five groups to consider concrete interventions in each context with a focus on self-awareness and potential of the people themselves.

\section{Business in its narrow meaning}

Depending on the purpose of a business, which can be profit maximizing or primarily focusing on solving problems, as well as the business's interfaces with poor people, its approach will vary. Providing products or services for a profit is the narrow meaning of business. In the case of the profit-maximizing approach, business has possible interfaces with such types of poor people as poor customers, poor employees, and the unemployed. The business pays attention to poor customers when the companies are required to respond to social issues and the poor can serve as a vast untapped market (A). In this interface, business can help improve lives of poor people through generating and supplying innovative products or services for their unmet needs, and at the same time explore new sources of growth (a specific discussion can be found at footnote 1). The rush of multinational companies to exploring poor markets at the so-called the bottom of the pyramid proposed by Prahalad and Hart (Prahalad and Hart 2002; Prahalad 2005) is an example of this interface. 
Interfaces between business and poor people

\begin{tabular}{|c|c|c|c|c|c|c|}
\hline & $\begin{array}{l}\text { Types of poor } \\
\text { people }\end{array}$ & A & B & $\mathrm{C}$ & $\mathrm{D}$ & $\mathrm{E}$ \\
\hline & Business & $\begin{array}{l}\text { Consumers/users } \\
\text { of products/ } \\
\text { services }\end{array}$ & Employees & $\begin{array}{l}\text { The unemployed, } \\
\text { who may obtain } \\
\text { employment from } \\
\text { enterprises }\end{array}$ & $\begin{array}{l}\text { Owners of } \\
\text { micro- and small } \\
\text { enterprises }\end{array}$ & $\begin{array}{l}\text { The dependents } \\
\text { of these poor } \\
\text { workers and } \\
\text { owners }\end{array}$ \\
\hline I & $\begin{array}{l}\text { Motives of } \\
\text { the interface }\end{array}$ & $\begin{array}{l}\text { New markets } \\
\text { Social } \\
\text { responsibility }\end{array}$ & \multicolumn{2}{|l|}{ Labor force } & $\begin{array}{l}\text { Desire to escape } \\
\text { from poverty }\end{array}$ & \\
\hline II & $\begin{array}{l}\text { Specific } \\
\text { mission of the } \\
\text { organization }\end{array}$ & \multicolumn{3}{|c|}{ Profit maximization and social responsibility } & $\begin{array}{l}\text { Business as a } \\
\text { tool to earn } \\
\text { income and } \\
\text { escape from } \\
\text { poverty. }\end{array}$ & \multirow{2}{*}{$\begin{array}{l}\text { Benefit from } \\
\text { businesses } \\
\text { where their } \\
\text { family members } \\
\text { are consumers, } \\
\text { employees, or } \\
\text { owners }\end{array}$} \\
\hline III & $\begin{array}{l}\text { How to make } \\
\text { good use of } \\
\text { its interfaces } \\
\text { with poor } \\
\text { people }\end{array}$ & $\begin{array}{l}\text { Generate } \\
\text { innovative } \\
\text { products or } \\
\text { services for unmet } \\
\text { needs }\end{array}$ & $\begin{array}{l}\text { Engage the } \\
\text { poor in market } \\
\text { research and } \\
\text { develop products } \\
\text { or services for } \\
\text { poor customers. }\end{array}$ & $\begin{array}{l}\text { Potential labor } \\
\text { force for exploring } \\
\text { markets of poor } \\
\text { people }\end{array}$ & $\begin{array}{l}\text { Business serves } \\
\text { as a tool to } \\
\text { deliver products } \\
\text { or services } \\
\text { produced by } \\
\text { employees to } \\
\text { consumers. }\end{array}$ & \\
\hline
\end{tabular}

However, the article argues that different from the interface with normal customers, the interface with poor customers has the goal oriented to achieving not merely profit maximizing. Whether the interface leads to poverty reduction is also important in this interface. Drucker (2008) put an emphasis on the purpose of a business as "customer creation," bringing about the satisfaction of the customer: "A business is not defined by the company's name, statutes, or articles of incorporation. It is defined by the want the customer satisfies when he buys a product or a service. To satisfy the customer is the mission and purpose of every business" (Drucker 2008). In this way, the success of goods or services is based on whether the customer is satisfied. However, when customers are poor people, business approaches to these poor customers are expected to be solutions, even though they are merely aiming to provide products or services for a profit. Therefore, the product or service is only a success if it fulfills the social responsibility that the defined problem has been solved. This is the key characteristic of business targeting the poor.

In the interfaces with poor employees and the unemployed (B and $\mathrm{C}$ ) as potential labor forces, business can contribute to poverty reduction by taking advantage of poor employees' deep understanding of poverty in developing and delivering products or services to poor consumers, engaging the poor in market research, and engaging them in production. However, it is important to generate innovations based on the capacity of these employees to achieve strong production and a suitable working environment. This helps produce good products based on the win-win relationship between employers and employees, not on labor exploitation.

\section{Business in its broad definition}

The interface of business with poor owners of micro- and small enterprises helps explore the broad definition of business. As mentioned above, business, with the 
broad definition of "someone's regular occupation, profession, or trade for some certain purpose," does not limit itself to the purpose of earning a profit. There are two important points to discuss here, as follows.

Business owner The word "business" is often associated with images of multinationals or local firms, but it is not limited to such organizations. As illustrated by the two cases of firms run by people with disabilities above, business can serve as a tool for them to escape poverty and at the same time solve the problems of other poor people. Business originates from their desire of breaking constraints around them, escaping from poverty, not for themselves alone, but for their families also. In this case, the narrow definition of business as "providing products or services" is also valid when the poor carry out these activities. Customers of these businesses can also be poor people, like in the case of Hoang Minh Co., Ltd. The specific point of this kind of business is that problem-solving products are created out of the ideas and resources of poor people. In the case of Duc Hien., though employees with disabilities cannot work well in a normal environment, there are no human beings without potential. For example, some employees are not in good health, but have knowledge and the ability to understand difficult techniques. Some have less knowledge but perform production tasks well. If these employees are placed individually in the production line, their potential will not be activated, and they cannot work alone as effective producers. However, if they work together in an innovative way in which the strengths of each cover for the weaknesses of the others, their team can will become a true production unit. For example, employees, who have good health work but do not understand well the difficult tasks, can work with those do not have good health but can perform the tasks well based on a division of labor between physical skill and technical knowledge.

Business purpose The broad definition of "business" does not positively mention any alternative purpose to the profit-making purpose in the narrow definition. The "rather-than-profit" side of business has been long neglected due to the trend to focus on the narrow definition. The two firms discussed above are oriented towards solving problems that people with disabilities face in daily life, taking in other disabled people, providing them education and vocational training. They develop creative products for disabled customers and creative methods of production for employees with disabilities to work with ease and make good use of their potential. This cannot be seen as a new category of business, since it is covered by the broad definition, and it has a long history. It is only new to those who have kept their eyes on sources of profit.

To sum up, adhering to the traditional focus on profit will not help business innovatively solve poverty issues. This does not mean that business should lose that focus, but it means that businesses should be aware of alternative sources of value that might come from interfaces with the poor as a market or labor pool with limitless potential. In this sense, the broader original definition of "business" as a regular occupation, profession, or trade takes in back to its original nature and opens the path to explore a new type of socially conscious business. This type of business challenges existing studies focusing on profit, since the theoretical base needed is substantially different. This is a promising area for further exploration and research. 


\section{Conclusion}

Business solutions to poverty are often discussed as ready-mades, solving poverty programmatically through job creation, products meeting the needs of the poor, government policies, etc. However, poverty cannot be regarded as a generic target, but should be investigated in its real diversity, in which the awareness and potential of poor people in various situations is an important factor in any business approach to poverty reduction. Though the case of PWDs in Vietnam is used here as one type of poor people, it may be a different story when applied to other forms. However, the case of PWDs illustrates that there is no cure-all method of the diversity of poverty issues. Furthermore, the paper points out that the self- awareness and potential of poor people are some among key factors in any solution to poverty. Therefore, business should take advantage of these factors to yield higher effectiveness through various interfaces with the poor. There are also many other types of business not limited to the purpose of profit. This opens a space for further studies on "not-for-profit" businesses, of which business oriented towards poverty alleviation is an important form.

Acknowledgments This research was partially supported by Grant-in-Aid for Research Activity Start-up of Japan Society for the Promotion of Science (no. 22830012). The author would like to thank Professor Seiichi Ohtaki, the editor, and anonymous reviewers for their constructive comments.

\section{References}

Brenner, R. (1983). History: the human gamble. Chicago: University of Chicago Press.

Caritas Vietnam (2010). Bao cao cua UBBAXH-CARITAS Viet Nam ve cac hoat dong tro giup nguoi khuyet tat (UBBAXH-CARITAS Vietnam Report of Aids to people with disabilities). http://www. caritasvietnam.org/Default.aspx?tabid=83\&ctl=ViewNewsDetail\&mid=368\&NewsPK=1346. Accessed 1 April 2011.

Dat, N.B. (2010). Tu van huong nghiep trong cong tac day nghe cho thanh nien, thieu nien khuyet tat, nan nhan chat doc hoa hoc (Job orientation and consultation for the young disabled, victims of agent orange/dioxin). http://ussh.vnu.edu.vn. Accessed 1 November 2011. (Vietnamese.)

Drucker, P. (1974). Management: tasks, responsibilities, practices. New York: Harper \& Row.

Drucker, P. (2008). Management (Revised Ednth ed.). New York: HarperCollins.

Duong, L. B., Hong, K. T., \& Vinh, N. D. (2008). People with disabilities in Vietnam: findings from a social survey at Thai Binh, Quang Nam. Da Nang and Dong Nai: National Political Publishing House.

Giang, T. (2010). Nguoi khuyet tat Vietnam - can hon nua nhung chia se (People with disabilities in Vietnam - the need of more share). Truyen thong Giao duc Suc khoe. www.t5g.org.vn. Accessed 1 April 2011. (Vietnamese)

Hamel, G. (2002). Leading the revolution. Boston, MA: Harvard Business School Press.

International Labor Organization. (2003). Working out of poverty. Geneva: International Labor Organization.

Karnani, A. (2007). The mirage of marketing to the bottom of the pyramid: how the private sector can help alleviate poverty. California Management Review, 49(4), 90-111.

Karnani, A. (2010). Failure of the libertarian approach to reducing poverty. Asian Business \& Management, 9, 5-21.

Minh, V. T. B. (2007). Khao sat doanh nghiep ve viec lam cua nguoi khuyet tat (The survey on employment of people with disabilities). Blue Ribbon Employer Council Report. www.ideavietnam.org. Accessed 1 April 2001. (Vietnamese).

Porter, M. E. \& Kramer, K. R (2006). Strategy society: the link between competitive advantage and corporate social responsibility. Harvard Business Review: 78-92.

Prahalad, C.K. (2005). The fortune at the bottom of the pyramid. Wharton School Publishing. 
Prahalad, C.K. \& Hart, S. L (2002). The fortune at the bottom of the pyramid. Strategy+Business, January, $2-14$.

Priestly, P., McGuire, J., Flegg, D., \& Welham, D. (1978). Social skills and personal problem solving: a handbook of methods. London: Tavistock Publications.

Reuters (2007). Pupils browse porn on donated laptops. http://www.reuters.com/article/2007/07/20/ us-nigeria-pornography-idUSL1966647020070720. Accessed 1 November 2011.

Sen, A. (1999). Development as freedom. Oxford: Oxford University Press.

Townsend, P. (2006). What is poverty? An historical perspective. In: D. Ehrenpreis (Ed.) Poverty in focus. Brasillia, Brazil: International Poverty Center, United National Development Programme, p.5.

USAID (2005). Vietnam disability situation assessment and program review. http://pdf.usaid.gov/pdf_docs/ Pdacf476.pdf. Accessed 1 April 2011.

Vandenberg, P. (2006). Poverty reduction through small enterprises: emerging consensus, unresolved issues, and ILO activities. International Labor Organization, SEED Working paper No. 75. http:// www.ilo.org/wcmsp5/groups/public/@ed_emp/@emp_ent/documents/publication/wcms_093981.pdf. Accessed 1 April 2010.

World Bank. (2000). World development report 2000/2001: attacking poverty. New York, NY: Oxford University Press.

Yunus, M. (2007). Banker to the poor: micro-lending and the battle against world poverty. New York, NY: PublicAffairs. 